\title{
Towards a Grown-Up Faith: Love as the Basis for Harry Potter's Self-Sacrifice
}

\author{
Sigrid Coenradie
}

\section{$\mathbf{1}$ \\ Introduction}

"Is it love again?", said Voldemort, his snake's face jeering. “Dumbledore's favourite solution, love, which he claimed conquered death, though love did not stop him falling from the Tower and breaking like an old waxwork. Love, which did not prevent me stamping out your Mudblood mother like a cockroach, Potter - and nobody seems to love you enough to run forwards this time, and take my curse". ${ }^{1}$

In Harry Potter and the Deathly Hallows, sacrifice is a predominant theme. Although there are differences - Harry Potter is but a fictive character, his sacrifice functions in a mythical, but not a religious setting - Joanne Rowling's story has some striking similarities to the biblical story of Abraham and Isaac, and the Quranic story of Ibrahim and his son. The parallels between Harry's sacrifice and the Passion cannot be missed either. The sacrifice of a son even turns into the sacrifice by a son in many re-readings of the Abraham-story. All are stories about the sacrifice of a son, and thereby shaping the identity of a community. Harry's sacrifice will enable us to look into this theme more profoundly.

The main question of this article is: Is Harry's action to be interpreted as a sacrifice, a self-sacrifice or as a gift? This, however, raises new questions, for example about the autonomy of the one being sacrificed, the necessity of violence commonly involved in sacrificial practices, and finally questions about the nature of self-sacrifice in a profane context. This article is structured accordingly and will consider 1 . Harry being sacrificed; 2. Harry's self-sacrifice; and a strangely combining variant I propose, 3. Harry's life being given. I will compare the above-mentioned biblical sacrifices to the one Harry makes.

The meaning of the term 'sacrifice' is ambiguous. Claudia Welz differentiates between a religious and a secularized meaning of the word sacrifice. ${ }^{2}$

1 Joanne K. Rowling, Harry Potter and the Deathly Hallows (London: Bloomsbury, 2007), 36.

2 Claudia Welz, "Love as Gift and Self-Sacrifice," in Neue Zeitschrift für Systematische Theologie und Religionsphilosophie 50 (Bd., 2008): 238-266. 
In its religious meaning it is an act of giving to God, which is motivated by the anticipation of receiving in return, as a successful communication with God. In its secularized meaning sacrifice implies deliberate loss and destruction, the renouncing or giving up of something valuable for the sake of a greater good. I define 'self-sacrifice' as the practice of offering one's life to gain something more valuable, e.g. an eternal life in heaven. I will argue that, although Harry Potter at the close of the final book is prepared to give his life for his friends, in the process he paradoxically receives his life as a gift. Furthermore, I claim this gift has nothing to do with magic, but can be regarded as old-fashioned religious grace. Therefore, I define 'gift' used in the context of 'sacrifice' as the receiving back of the life that has been offered in self-sacrifice.

In this article no specific literary method is applied. I do not search for causal connections or inter-textual relations. According to Paul Ricoeur narratives offer a possible world and an opportunity for identification. In the following, the novels on Harry Potter are placed in a context of religious studies on sacrifice and its meanings. The question is if, and if so, how, an analysis of Harry Potter's sacrifice can contribute to a philosophical-theological reflection on (self)sacrifice.

From the start it is clear that Harry Potter is in a privileged position, comparable to Abraham, who is called out of Ur, and Jesus who was announced by John the Baptist as a very special person. Harry is "the Chosen One", who survived an assassination attempt by the evil wizard Voldemort. Therefore, Harry is destined to fight Voldemort and save the Hogwarts school community. Throughout the seven volumes of the Potter series, however, the reader gradually becomes aware that Harry cannot defeat Voldemort without laying down his own life. When, in the second part of the last book, Harry discovers this dilemma, he feels betrayed and used by the school's headmaster Dumbledore. I will argue that the free choice Harry has to make regarding his being sacrificed, forms a necessary condition for all acts of self-sacrifice. Furthermore, one wonders how Harry's sacrifice can be interpreted. Is Harry's self-sacrifice an act of violence against self in order to prevent violence against others, as Derrida states? Can Harry's self-sacrifice be interpreted as an altruistic sacrifice instead of an egoistic one, in line with the difference Schiller suggested? I will argue: Neither. Harry's self-sacrifice does not seem to be understandable adequately in terms of a sacrifice. Its meaning has to be re-phrased in terms of a gift.

\subsection{Summary}

For those who did not read the series: The main character, Harry Potter, is an orphan. His parents were killed by the evil wizard Tom Riddle, whose nickname is Lord Voldemort. One-year-old Harry survived the attack. Harry is left to stay 
with his only remaining family: His uncle and aunt and their spoiled son. This family of muggles (non-wizards) mistreats the young Harry. The series starts when Harry is eleven years old and is invited to enter Hogwarts School of Witchcraft and Wizardry, the setting for most of the books. In each volume, Harry is one year older and the author J. K. Rowling introduces issues consistent with Harry's age at the time. During his first trip on the train to Hogwarts, Harry meets Ron and Hermione. They develop a strong friendship and then fight Voldemort, who is a constant threat to the happy Hogwarts society, together. The last volume, Harry Potter and the Deathly Hallows, is completely devoted to the accomplishment of Harry's mission to conquer Voldemort, through his self-sacrifice. As will be argued, Harry's self-sacrifice is not motivated by fear, duty or a higher principle. Harry relinquishes his life out of love and with the help of the Hogwarts community.

\subsection{A Life Based on Sacrifice Out of Love}

Harry's very existence is based on sacrifice, as his mother Lily was protecting him with her life when she was killed by the evil wizard Voldemort. Harry survived the attack. He is the "Boy who lived", the "Chosen One". The scar on his forehead, which he received the night his parents died, reminds him, and everyone who meets him, of his destiny. That destiny is to conquer Voldemort, who is still after Harry and wants to conquer the wizard world, out of revenge. Not until the fifth volume does the reader learn what motivated Voldemort to try and kill Harry. It is a prophecy, which states that neither Harry nor Voldemort could live while the other survived:

The one with the power to vanquish the Dark Lord approaches (...) and the Dark Lord will mark him as his equal, but he will have power the Dark Lord knows not (...) and either must die at the hand of the other for neither can live while the other survives $(. ..){ }^{3}$

The prophecy functions as a meta-narrative that seems to justify the violence against Harry. However, Nikolaus Wandinger, who compares the sacrifices of Harry Potter, of the school's headmaster Dumbledore, of teacher Snape and of other characters in the books, has pointed out that this prophecy ironically

3 Joanne K. Rowling, Harry Potter and the order of the Phoenix (London: Barnes \& Noble, 2003), $37,741$. 
became self-fulfilling only after Voldemort's evil action. ${ }^{4}$ The prophecy was no inescapable fate. It had no power of its own. ${ }^{5}$ By acting out of fear, ${ }^{6}$ moreover, by transferring the ability of talking Parsletongue (snake language) and establishing a mind connection, Voldemort himself created his opponent. In the end his down-fall is a self-judgment. ${ }^{7}$

\subsection{Horcruxes}

There is yet more to the relationship between Lord Voldemort and Harry Potter. As the story unfolds, it becomes clear that Harry is one of seven Horcruxes created by Lord Voldemort. Horcruxes are fragments of his soul. As is clear from his name, vol-de-mort (fleeing death), Voldemort's aim is to become immortal. Dividing his soul among the Horcruxes is a way of spreading the risk of death. However, creating a Horcrux has its prize, as it requires a murder to split the soul, and a spell to encase it. Furthermore, the creation of a Horcrux dehumanizes the murderer by mutilating his soul. ${ }^{8}$

The night Harry Potter received his scar Voldemort gave Lily the choice to save herself, for it was the baby he wanted. She did not have to die. Yet, she chose to die for Harry. This sacrifice of his mother protected Harry. ${ }^{9}$ During the assassination assault on Harry, the deathly curse used by Voldemort, "Avada Kedavra!" backfired on himself, thanks to the protection formed by the love of Lily Potter. Consequently two things happened:Voldemort was heavily injured.

4 Nikolaus Wandinger, "Sacrifice in the Harry Potter Series from a Girardian Perspective," Contagion - Journal of Violence, Mimesis and Culture 17 (2010), 27-51. In this article I draw heavily from Wandinger's work. In his article Wandinger reflects on the different kinds of sacrifices of the main characters in de series, in line with René Girard, who distinguishes between a pre-Biblical and a post-Biblical concept of sacrifice. Yet, while Wandinger's article focuses on the mimesis theory in comparing the sacrifices of the main characters in the series, this article concentrates on the question whether Harry has a free choice in sacrificing himself.

5 Cf. Hetty Zock, "Cultural Anxieties in Harry Potter and the Half-Blood Prince: Evil and the Magic of Human Abilities," in At the Crossroads of Art and Religion: Imagination, Commitment, Transcendence, (ed. Hetty Zock; Leuven: Peeters, Paris: Walpole, 2008); Groningen Studies in Cultural Exchange, vol. 34, 101-115.

6 Hetty Zock, "Cultural Anxieties," 52.

7 Cf. Nikolaus Wandinger, "Girardian Perspective," 7.

8 Joanne K. Rowling, Harry Potter and the Half-Blood Prince (London: Bloomsbury, 2005), 469.

9 Dumbledore explains to Harry: “... your mother died to save you. She gave you a lingering protection he never expected, a protection that flows in your veins to this day. I put my trust, therefore, in your mother's blood (...) Your mother's sacrifice made the bond of blood the strongest shield I could give you." Rowling, The Order of the Phoenix, 37, 736-737. 
Having no bodily form of his own, he becomes dependant on his servant Peter Pettigrew and his army of Death Eaters until the end of Harry Potter and the Goblet of Fire, in which Pettigrew helps Voldemort to regain his body. The other consequence of the assassination gone wrong is that Lily's death accidentally created a seventh Horcrux. A piece of Lord Voldemort's soul lives within Harry, without Voldemort knowing it. It seems that, according to Rowling, good and evil are intrinsically connected. Good carries evil within it and evil can be transformed into good.

At the end of Harry Potter and the Goblet of Fire, Harry is in the finals of the Tri-Wizard Tournament, which takes place in a labyrinth. This setting provides an opportunity for Lord Voldemort to isolate Harry and to order his servant Pettigrew to take a bone from his father's grave, give his own hand voluntarily and take Harry's blood by force, to recreate a body for himself. ${ }^{10}$

After this event, through the blood-connection between Harry and Voldemort, Harry is able to 'read' Voldemort's mind and feel his emotions via his scar more clearly than before. Now that he has a body again, the power of Lord Voldemort increases. Harry prepares the school by forming a group of pupils which he trains in witchcraft to be able to defend Hogwarts, in case the Death Eaters attack. This group is called after the school's headmaster: Dumbledore's army. When the Ministry of Magic finds out about the existence of Dumbledore's army, the headmaster is fired and has to leave Hogwarts. At the end of volume six, however, Dumbledore confides his secret mission to Harry: He informs him that he is chasing the Horcruxes, although he hides the most important piece of information: His presumption that Harry is a Horcrux himself. On one of these secret missions Dumbledore gets poisoned, which indirectly causes his death. Only in the last volume does Harry, with the help

10 As Wandinger points out, this scene shows a perfect primordial sacrifice, for the Death Eaters, summoned up by Voldemort to attend the humiliation and torture of Harry, function as a mob, encircling and threatening one lonely individual, intending to kill him. Even the blood is there. Nikolaus Wandinger, "Harry Potter and the Art of Theology: A Theological Perspective on J. K. Rowling's novels - Part Two: Sacrifice and Mission," in Milltown Studies 53 (Summer 2004), 31-153. Wandinger furthermore distinguishes between the sacrifice (or better: self-mutilation) of Peter Pettigrew's hand, which is a sacrifice out of fear and the sacrifice of Harry, which is a sacrifice out of love. 
of his friends Ron and Hermione, try to destroy some of the Horcruxes himself. Considering his lack of success, the prophecy and the scar hurting Harry while contacting Voldemort, we get the impression that Harry has been called to a mission impossible.

Gradually, Harry begins to presume he cannot defeat his enemy by fighting. By recollecting the memories of the late Severus Snape, teacher of the dark arts, from the 'Pensieve', Harry learns the only way to conquer Voldemort is through his own death. Finally, the idea that he has to surrender to Voldemort without defending himself enters his mind.

\subsection{Sacrificed}

From the Pensieve, ${ }^{11}$ Harry learns that Dumbledore seemed to be willing to sacrifice Harry. Dumbledore himself gave up his own life deliberately in a calculated attempt to prevent Voldemort from laying his hands on the Elder Wand, which actually failed. The Elder Wand is the 'master' of all other wands and therefore the most desirable thing for Voldemort to possess. According to Wandinger, Dumbledore thinks along the logic of Caiaphas, who rather let one man, Jesus, die, than have the whole nation destroyed. ${ }^{12}$ At the end of the series, Severus Snape accuses Dumbledore of using Harry as a means to reach a higher goal: "We only kept him alive to let him die at the proper moment".13 Dumbledore replies, however, that keeping one's life is not the essential value. ${ }^{14}$

11 A Pensieve is a bowl in which one can read the thoughts of a person given voluntarily. It is first mentioned in Harry Potter and the Goblet of Fire.

12 Wandinger, "Sacrifice in Harry Potter from a Girardian Perspective," 35. The bible passage is John 11, $5^{0 .}$

13 When, at the end of the last volume, Harry walks into the Forbidden Forest to surrender himself to Lord Voldemort, his thoughts are most cynical: "Now he saw that his lifespan had always been determined by how long it took to eliminate all the Horcruxes. Dumbledore had passed the job of destroying them to him, and obediently he had continued to chip away at the bonds tying not only Voldemort, but himself, to life! How neat, how elegant, not to waste any more lives, but to give the dangerous task to the boy who had already been marked for slaughter, and whose death would not be a calamity, but another blow against Voldemort." Rowling, The Deathly Hallows, 34, 555. This reaction shows that Harry's motive and goal of his love is life, not death.

14 Lord Voldemort tries to flee death because he cannot imagine anything "worse than death", as Dumbledore says to him: "Your failure to understand that there are things much worse than death has always been your greatest weakness" Rowling, The Order of the Phoenix, 895. Dumbledore's advice to Harry is: "Do not pity the dead, Harry. Pity the living, and above all, those who live without love". Rowling, The Deathly Hallows, 578. 
As Dumbledore says in Chamber of Secrets, death is not the worst fate that can befall someone. Loyalty and friendship are valued more highly than life. In line with this principle, Dumbledore seemed to have been prepared to sacrifice Harry for the sake of the Hogwarts community.

\section{$2.2 \quad$ The Necessity of Choice}

Yet, as Ismael in the Ibrahim-story, Harry is almost grown up. ${ }^{15}$ He has a choice of whether to comply. One's autonomy, in the sense of the freedom and the necessity of making choices of your own, is stressed throughout the series. Tom Riddle (Voldemort) has a choice as well. Rowling describes the similarities between the boys. Both their mothers died at a young age. Their wands contain the phoenix feather from Fawkes, Dumbledore's bird. Their witchcraft is of the same strength. ${ }^{16}$ Like Voldemort, Harry must also come to terms with his disappointment in his father and the father-figures in his life. By stressing the resemblance between the boys, Rowling seems to point out that the difference between good and evil is not absolute. It is not the circumstances that determine who they are. The dividing difference between Harry and Tom is their moral behaviour. ${ }^{17}$ Whereas Voldemort is sacrificing others to the god of his own self, in his striving to obtain immortality, Harry chooses differently, being prepared to sacrifice his life for his friends. Harry's choices are all life-giving: Harry shows mercy to Peter Pettigrew, who betrayed his parents and saves the life of his opponent Draco Malfoy. He even makes an attempt to persuade Voldemort: "Try for some remorse, Riddle (...) It's your last chance".18

\subsection{Hallows or Horcruxes?}

As the number of followers of Voldemort increases rapidly, the school is not a safe place anymore. Harry is on the run, envy separates him from his best friend Ron, who temporarily breaks up with him. Harry is on the verge of despair, not knowing what to do or who can be trusted. In the second half of the book Harry must decide where his loyalty lies. Friendship is tested heavily. Basically,

\footnotetext{
15 Over the books, each book covering a school-year and consequently a year in Harry's existence, Harry becomes an adult.

16 Therefore, the Sorting Hat hesitates before putting Harry in Gryffindor, instead of Slytherin House, the house of Voldemort. Here again it is by Harry's own choice that he enters Gryffindor. See Joanne K. Rowling, Harry Potter and the Philosopher's Stone (London: Bloomsbury, 1997), 91.

17 "It is our choices, Harry, that show what we truly are, far more than our abilities", says Dumbledore. Joanne K. Rowling, Harry Potter and the Chamber of Secrets (London: Bloomsbury, 1998), 245 .

18 Rowling, The Deathly Hallows, 594.
} 
Harry has two choices: Collecting Hallows or chasing Horcruxes. Dumbledore has left a testament in which he donates a copy of the old fairy tale of the three Deathly Hallows to Hermione. The Deathly Hallows consist of the Elder wand, which makes one invincible, the Resurrection Stone, which brings back the dead and an Invisibility Cloak that hides one even from death. Together these three things defy death. As events unfold, the fairy tale appears to be reality: The three things do exist. By collecting them, Harry would become all-mighty and could easily beat Voldemort. Like Jesus tempted by the devil in the desert, Harry is attracted to the idea of becoming popular and powerful himself for a good part of the book. Eventually, however, he chooses to hunt the Horcruxes. As a Jesus-like figure, Harry abstains from the seduction of power and chooses a vulnerable way of life that involves suffering and self-sacrifice, but eventually results in a permanent defeat of evil.

\subsection{Crisis}

Apart from the free choice Harry has, there is also the aspect of autonomy. For Harry to make his own choices, eventually even against his school headmaster, he has to be grown-up. Dumbledore seeming unreliable, Harry has no higher authority to fall back upon. At the end of the series, Harry has to make decisions on his own, without any help. In the beginning of his career at Hogwarts, Harry has full trust in the school and its headmaster, who is like a father to him. That changes in the last volume. After Dumbledore's death Harry is disappointed to hear that Dumbledore did not tell the truth and withheld the essential information of Harry being a Horcrux. It was Dumbledore who told Harry that his ability of love and friendship could make the significant difference in defeating the enemy. ${ }^{19}$ However, it is the same Dumbledore, who keeps Harry unaware of the depth of the relationship between Harry and Voldemort and of the events, known or orchestrated by Dumbledore, involving the battle against Voldemort. As a consequence, Harry's firm trust in a set of values like loyalty and friendship and love evaporates. At this point, Harry's situation can be compared to that of Isaac in Genesis 22. Both seem to have unreliable fathers. In various literary works about Isaac, the boy never recovers from the shock of his father being prepared to sacrifice him. Harry feels equally abandoned and at a loss. In this sense, Harry Potter and the Deathly Hallows can be read as a metaphor about man's struggle to have faith, while living in a de-sacralised world. If one cannot count on God's fidelity, how can one count on God at all? Harry's 'god' has fallen from his pedestal, leaving him to his own devices. This

19 Indeed, as the story unfolds, Harry develops a strong friendship with Ron and Hermione, allowing them to accomplish what neither of them could have done alone. 
represents a common human experience after the 'death' of God: God remains silent and seems to be indifferent to the suffering of people.

\subsection{The Death of God}

Nietzsche called this experience the 'death' of God. People killed the gods without being aware of the consequence: Their loneliness. What people find after this very last stage of sacrificing is not a sacred place; it is an empty place, a fall into an abyss. In this emptiness one can only 'meet' the absence of God. One stays behind in a de-sacralised world. In accordance with Nietzsche, Bataille interprets the death of God as the ultimate sacrifice modern culture can make. Bataille, however, goes further and considers the consequences by asking questions, e.g. which God has been sacrificed here? Is it the 'old' God? Is it - to be more specific - a certain image of God that got lost? Does one have to become one's own God? Bataille starts his theory with the last question, by stating that one has misused God, by making Him into an object that can be appropriated. Instead of sacrificing to God to maintain one's life one must sacrifice one's life. In the process, one's autonomy, in the sense of making free choices, was sacrificed. Therefore, Bataille's version of the death of God is that people must voluntarily sacrifice themselves. However, in giving up their lives, they paradoxically will find they can keep their lives.

In comparison to the clerical practice, through the loss of a priest in the course of secularisation, one has to bring a sacrifice oneself, without the help of somebody who performs the act on your behalf. According to René Girard, in line with the Greek drama, a sacrifice can be understood as the internal aggression of a community directed at an innocent victim. A priest was symbolically inflicting human violence of many against one to re-establish order and peace within the community, thus presenting and legitimizing sacrifice as a divine necessity in religion. However, in a post-modern world re-establishing a community's relationship with the divine by killing or removing a scapegoat is problematic. Sacrificial violence commonly involves the unwilling participation of the victim and a sovereign Other, who, behaving in an authoritarian manner, forces people to comply. Victims have to be duped or brainwashed to accept their place in the ritual.

Here, the difference between Voldemort forcing his servant Pettigrew to donate his hand and Dumbledore refraining from demanding Harry to sacrifice his life, is illustrative. A sacrifice out of love will not demand anything in return. The renunciation of a reward, in the form of gratitude, other's approval and admiration, is part of the sacrifice. Besides, an authority asking someone to give up his of her life for a greater goal or moral principle, places an unacceptable claim on that person. In the case of the under-age Harry, that 
would mean psychic violence. ${ }^{20}$ Harry can only surrender himself by free choice, that is as a moral agent. The term agent, however, does not accord with Harry's actions, which may look like obedience, but are nevertheless done freely. Harry is free to follow the ethical principles of his own reasoning. The term autonomy, however, fails to take into account the community, while in Harry's case the values of the Hogwarts community are crucial for his decision to surrender himself. The external values imposed on Harry by Dumbledore and internalized by Harry during his youth at Hogwarts, play a decisive role. A community can have a huge impact on shaping understandings and enactments of individual morality. Therefore, Bucar introduces the term dianomy, which recognizes that both the individual and the community are important in moral decision-making. ${ }^{21}$ In relation to God, one needs to be dianomous, no matter how unequal the relationship is. Secularisation, therefore, is seen by Frits de Lange not only as a process of decreasing metaphysical religiosity, but as an increasing awareness of the sacrificial character of religion as well. ${ }^{22}$ Since the death of God, through a phase of nihilism and secularisation, a new idea is given to us in art, film and literature. It is the idea that responsibility lies with each and everyone.

\section{3} Harry's Self-Sacrifice?

Sacrifice differs from self-sacrifice with regard to its goal. By means of sacrifice one tries to connect to the gods, to enter a sacred place. The secret of the sacrifice lies within the identification of becoming sacred. Self-sacrifice is an exception to this practice. By self-sacrifice the life of the sacrificer ends, and with it the need to sacrifice. Derrida points to this paradox of sacrifice, stating that religion both requires and excludes sacrifice. ${ }^{23}$ One uses violence in the name of non-violence to avoid violating others. Even if the use of violence is

20 In this respect, Dumbledore is morally wrong forcing Snape to kill him, as the latter is well aware: "And my soul Dumbledore? Mine?" Rowling, The Deathly Hallows, 548. Cf. Wandinger, "Sacrifice in Harry Potter from a Girardian Perspective," 31.

21 Cf. Elizabeth M. Bucar, "Dianomy: Understanding Religious Women's Moral Agency as Creative Conformity," in Journal of the American Academy of Religion, 78 (2010): 662-686 (665).

22 Frits de Lange, "Kenotic Ethics," in Letting go: Rethinking Kenosis (ed. Onno Zijlstra; Bern: Peter Lang, 2002), 59 .

23 Jacques Derrida, "Faith and Knowledge: the Two Sources of 'Religion' at the Limits of Reason Alone," in Religion (eds Jacques Derrida and Gianni Vattimo; Stanford: Stanford University Press, 1998), 1-78 (52). 
unavoidable, in religions it is unacceptable to subject other life to this kind of violence. Therefore, "absolute respect" requires self-sacrifice. The ambivalence of self-sacrifice, however, is that one must use violence against oneself in order not to subject others to violence. By self-sacrifice one extinguishes not only one's life, but also the connection to the sacred. What motive is left for self-sacrifice?

\subsection{Egoistic and Altruistic Self-Sacrifice}

In his comment on Derrida, Dalferth, reflecting on a dialogue in Schiller's Theosophie des Julius, introduces the difference between egoistic and altruistic self-sacrifice. ${ }^{24}$ Schiller makes a distinction between egoistic self-sacrifice, which is carried out in hope of an eternal remuneration, and an altruistic selfsacrifice, which is carried out for the well-being of all others. In a discussion between Julius and his friend Raphael in Schiller's text, the question arises how one can benefit from self-sacrifice. A possible answer may be found in immortality. But that would exclude the possibility of a truly altruistic self-sacrifice. Desire for immortality, and using self-sacrifice to reach this goal, would destroy the pure orientation on the other. Consequently, Dalferth states that "the decisive difference is not between sacrifice and self-sacrifice, but between egoistic and altruistic self-sacrifice, on the one hand, and between an act of violence and an act of love on the other". ${ }^{25}$ In his view, love is greater than both. Love overcomes both sacrifice and self-sacrifice by refraining from violence even at the cost of losing one's life. Therefore, loss of life out of love is not an intentional gift for others, whether given out of selfish or unselfish motives. Harry accepts the consequences of his love without awareness of the outcome. He "loves the others to death".

\subsection{Harry's Voluntary Self-Sacrifice}

As we have seen, Harry Potter is not aiming at immortality. Consequently, his self-sacrifice must be an altruistic self-sacrifice, voluntary undertaken. For Harry's sacrifice to be a self-sacrifice he has to be a grown-up for the sacrifice to be a free choice and to have its full meaning. Like Abraham in Genesis 22, Harry is tested in the school-contest in volume four. What is being tested? Not

\footnotetext{
24 Fr. Schiller, "Philosophisch-Ästhetische Schriften, Theosophie des Julius," in Sämtliche Werke 5 (1975): 344-358. Cited in I. U. Dalferth, "Self-sacrifice: from the act of violence to the violence of love," International journal for philosophy of religion 68 (2010), 77-94.

25 Dalferth, "Self-sacrifice," 80.
} 
his witchcraft. His loyalty to the community is tested. ${ }^{26}$ In the contest Harry appears to be willing to share information with his opponents, helping them, warning others and saving others from drowning. Here Harry learns to make choices of his own. By not fulfilling his destiny to win the contest and consequently become popular, but by refusing to fight the others, Harry will save lives and gain in the end.

Basically, he discovers: Destiny is not fate, identity is not destiny. One's autonomous choices make the difference between good and evil. In his interpretation of the Koran's Sura 37:100-110, (see the essay: Sacrifice and Islamic identity further on), Abdelilah Ljamai states that it is essential that the son volunteers for the sacrifice. So the true sacrifice is self-sacrifice. It is only by giving up his life, that one could keep it. The same goes for Harry. In contrast to the sacrifice of Isaac/Ismael there is no substitute. Like Jesus in the New Testament, Harry dies and after a kind of afterlife scene, in which he meets Dumbledore again, he is 'risen'. Nevertheless, Harry, like Jesus, is in great despair at the time of his self-sacrifice. The former unquestioned trust has vanished after Dumbledore died - as if God remains silent. Doubt is fundamental. Harry wonders whether Dumbledore had ever cared about him.

Look what he asked from me, Hermione! Risk your life, Harry! And again! And again! And don't expect me to explain everything, just trust me

26 In this article, Dalferth states that Abraham, placed into the dilemma whether obeying a God, whose behavior contradicts itself, remains silent. As God has become incomprehensible and inaccessible as a dialogue partner, the conflict cannot be solved by reasoning. Therefore, Abraham is putting God to the test. He challenges God to be either reliable or to take leave of his people and cease to be their God. Ibid, 86 and 87, see also note 24. Cf. The Silence of God, in which the authors also interpret Abraham's silence as Abraham testing God's trustworthiness. Marjo Korpel and Johannes de Moor, The Silence of God (Leiden: Brill Academic Pub, 2011), 39. Cf. Adele Wiseman, The Sacrifice, (Toronto: McClelland, 1956, 2001). In this Canadian novel the main character Abraham interprets the moment when the biblical Abraham lifts his knife to slay Isaac, as follows: "In that moment lay the future of our people, and even more than that. In that moment lay the secrets of life and death, in that closed circle with just the three of them, with Abraham offering the whole of the past and the future, and Isaac lying very still, so as not to spoil the sacrifice (...). And God himself is bound at that moment, for it is the point of mutual surrender, the one thing He cannot resist, a faith so absolute (...). That was the moment that even God could not resist, and so He gave us the future." (199). This novel suggests that God responds to absolute faith by keeping his promise. 
blindly, trust that I know what I'm doing, trust me even though I don't trust you! Never the whole truth! Never! ${ }^{27}$

Self-sacrifice is not easily made, but accompanied by despair and doubt. Shall I be loved? Can this fundamental doubt be avoided?

As Marcel Poorthuis stresses in his article on Gertrud von le Fort further on, "a sacrifice brought willingly and without hesitation runs the risk of being no sacrifice at all". Had Harry been certain of the outcome, known that his death would bring victory, his sacrifice would not truly have been a sacrifice.

We run into a paradox here. In the Potter story, self-sacrifice is a free and conscious decision, made by a responsible, autonomous individual. If the one being sacrificed has full knowledge and trust, there is no need to sacrifice in the first place. Then, what motivates the doubting, unaware and disappointed Harry to continue at the end?

\subsection{Harry's Sacrifice Forming the School-Identity}

So far, we have seen that Harry's sacrifice is not demanded by an authority, not the outcome of calculation, nor motivated by fear or duty or even love as a higher principle. It is a voluntary self-sacrifice out of love for the community and supported by that community. Therefore, Harry needs to come to terms with his beloved ones, even when they are dead, despite his anger and disappointment. Before he can surrender himself to Voldemort, Harry has had to confront and forgive Dumbledore's faults and selfishness. For his self-sacrifice it is vital that Harry understands and accepts his fallibility, and by extension his own. The underlying question Rowling raises, is whether Harry can pity Voldemort who wants to kill him in the end.

Here the role of witnesses arises: The self-sacrifice out of love must to some extent be deliberately and publicly undertaken. Harry cannot do this alone. He needs and gets all the moral and practical support at Hogwarts, because the community is in essence the source, as well as the aim, of his love. Rowling's story shows the importance of the role of the public and the importance of the sacrifice being a ceremony. At the final moment, when he is about to lose control, which is a necessary part of any sacrifice, the Resurrection Stone opens. Walking through the Forbidden Forest, about to surrender himself, Harry is accompanied by the spirits of his beloved ones: His parents and his godfather Sirius and the mentor Lupin, all representing the community, its members

27 Rowling, The Deathly Hallows, 295. The resemblance to the desperation of Jesus Christ in Gethsemane is striking. Cf. Wandinger, "Sacrifice in Harry Potter from a Girardian Perspective," 47 . 
willing to fight next to him. His father assures Harry they will stay with him "until the very end". ${ }^{28}$ Rowling presents Harry's sacrifice as an answer to the love he received, as an antidote to the selfish love of Voldemort, who only loves himself at the expense of his family and the Hogwarts community.

Seen in this light, Harry's sacrifice is an answer to the sacrifices made by his mother, his stepfather Sirius, his teacher Snape and his mentor Lupin. Harry undertakes his sacrifice as a willed and intentional act. He can do so because he is grown up. The sacrifice transforms him and finally allows him to become a subject. Still, Harry's sacrifice is not to be reconstructed as an experience 'of' the subject. Without defending himself, Harry exposes himself to Voldemort, who does not hesitate to cast the Death Curse. Because of Harry's blood in Voldemort, however, it turns out the latter's death curse cannot be effective. The next moment Harry finds himself in a kind of after-life scene on a heavenly railway station: King's Cross. Here Harry meets Dumbledore, who repents and explains his motives to Harry. Then Harry wonders whether he still has a choice, which Dumbledore confirms. Harry can either take a train, or return to finish the job.

\subsection{The Voluntary Offer Refused}

Harry returns. From this moment on the outcome is no surprise. In the big entrance hall of the school, Harry's final victory, for all to see, will take place. Voldemort is trying to demoralize the school population: "Harry Potter is dead! Do you understand now, deluded ones? He was nothing, ever, but a boy who relied on others to sacrifice themselves for him!". ${ }^{29}$ It is of note that Voldemort accuses Harry of what he himself has done all his life. ${ }^{30}$ However, the community reacts furiously. In contrast to the book, the film shows us a very biblical reaction at this point. Neville Longbottom steps forward to oppose Voldemort. "Harry is dead", he shouts for everyone to hear, "so many have died in this battle, but they now live in here [points], in our hearts. We will go on". The following final Battle of Hogwarts is rich with examples of smaller and greater sacrifices, which motivate Harry to confront Voldemort. When Voldemort casts the

\footnotetext{
28 Rowling, The Deathly Hallows, 561.

29 Rowling, The Deathly Hallows, 36; 585.

30 Cf. Wandinger, "Sacrifice in Harry Potter," 57.
} 
killing curse on Harry, the Elder Wand knows its true master and it re-bounds the curse on Voldemort, who now is unprotected by Horcruxes.

Voluntary substitution occurs in contexts of a generous offer by someone to take the place of someone under threat. Biblical examples are Judah, who offers himself for this youngest brother, Benjamin (Gen. 44, 33). Moses, as intercessor on behalf of his sinful nation, is willing to have his name excised from God's book if God will accept him as a substitute for the nation (Ex. 32, $3^{30}-3^{2}$ ) and Paul expresses a similar wish (Rom. 9,3). However, these sacrifices are not accepted. Neither is Harry's. Therefore, these sacrifices out of unrestricted love are no sacrifices at all. In the end, these 'prophets' give nothing; on the contrary, they receive life. As Girard and Bataille state in reaction to Nietzsche, sacrifices relate humanity to the Divine. Sacrificing demands repetition in a ritual. Perhaps it is not a coincidence we see sacrificing elements in successful books and films of the last two decades, like The Matrix, The Lord of the Rings and The Narnia Chronicles. In the Potter series, Rowling shows a community surviving through sacrifices made by their moral leaders. In contrast to the 'old' concept of sacrifice, no violence is committed against the victims to force them. On the contrary: Harry happens to re-establish the Hogwarts society by withdrawing from action, in relinquishing revenge, in laying down his life without defending it. His rescue is a gift. It breaks with the calculation of the $u t$ des principle. ${ }^{31}$ In the very act of laying down his life, Harry remarkably receives his life at the same moment. In a religious perspective and compared to the sacrifice of Jesus: One could state that God gives, and his gift transcends that of the sacrificer. Likewise, God had given the ram in the story of the sacrifice of Isaac, He gives Himself in the sacrifice as a sacrifié. So, when Genesis 22 is compared with the Harry Potter story, we see that in a post-religious context:

- Sacrifices are needed to restore relationships between a community and its tradition, the tradition in Harry's case being a wizard world;

- one has to bring a sacrifice oneself, since a God is lacking and consequently no substitution is available;

- one can only sacrifice oneself voluntarily;

- one cannot sacrifice oneself without help from a community.

\subsection{Final Remarks}

Compared to Dalferth's concept of self-sacrifice out of love, Harry's selfsacrifice has one unique feature: Harry does not die, or, if you wish, he receives

31 This is the principle that you give a sacrifice to the gods, to receive prosperity, good health and a long life in return. 
his life back. During the series, Harry never kills; Voldemort is killed by his own rebounding curse. In this respect, Harry's self-sacrifice differs from the suicide of e.g. bombing terrorists. Both could be altruistic sacrifices, motivated by religious ends and love. However, the love of a self-sacrificing terrorist is limited to a certain group and damaging another group. In contrast, Harry's love is extended to all others, even to Voldemort. By choosing not to defend himself, Harry submits himself to death. However, his surrender is not a death wish. His intention is to carry out a life-bringing mission. What is sacrificial about Harry's death is not his willingness to die, but his determined commitment to let others live. He voluntary relinquishes his life in accepting his destiny as an amor fati (Nietzsche). His offer does not cause killing, not even of himself. The giving rather than taking of live forms a fundamental reorientation. It is remarkable that the context of Harry's self-sacrifice is a secular one, although Rowling has modelled Harry Potter after the example of Jesus.

\subsection{The End}

In line with the others volumes, Deathly Hallows ends with a Great Banquet. Unlike other volumes, however, in this communion there is no distinction between the houses, symbolizing the re-unification of the Hogwarts community: "Nobody was sitting according to house any more: All were jumbled together, teachers and pupils, ghosts and parents, centaurs and house-elves". ${ }^{2}$ Selfish love (Voldemort) victimizes others, while self-giving love (Harry) eliminates boundaries.

\section{5}

\section{Conclusion}

In conclusion, we can say Harry's sacrifice is modern, after the "death of God" (Nietzsche). Analogous with the descriptions of the son of Abraham in the Jewish comments and Ismael in the Qur'an, Harry voluntarily relinquishes his life. He has to be an adult to be able to choose. Up to the very end, to the moment of sacrifice and of surrendering himself, Harry never loses dianomy. As in the religious stories, in the Harry Potter series love does not 'require' a sacrifice. De facto it ends up to be a self-offering out of love. While Isaac can be seen as pre-figuring Christ, Harry can be looked upon as post-figuring Christ. In line with the sacrifice of Jesus, Harry's sacrifice brings life, not death. In this sense, his sacrifice can be seen as a religious sacrifice performed in a modern, secular context, although on a narrative level.

Rowling, The Deathly Hallows, 596. 
This article shows that Harry voluntarily relinquishes his life, without fighting the enemy, whose history and position is very similar to Harry's. Their choices make all the difference. While sacrificial violence commonly involves the unwilling participation of the victim, Harry is not being sacrificed, but sacrifices his life willingly and without violence. Help from his beloved ones, and above all, pity for Voldemort, enable Harry to save both his world and his life, which he receives back as a gift. This gift seems to lead to a surplus rather than a loss. As Levinas has stated, self-sacrifice is one's being sacrificed rather than sacrificing oneself. ${ }^{33}$ In line with this passive attitude, in which a sacrifice is 'imposed' on a subject, who is unable to dissociate himself or herself from the vulnerability and suffering of another, one could argue Harry is sacrificed. In this sense, Harry's sacrifice is an answer to his mother's sacrifice. ${ }^{34}$ Usually, the idea of love as self-sacrifice suggests self-diminishment or even self-destruction. Applied to Harry Potter's sacrifice the idea of love as gift is more appropriate, which suggests that the self receives in giving itself. While giving himself, Harry is receiving a gift of selfhood. His sacrifice has to be rephrased as "self-giving", in the sense of "gift of self", for his giving away turns into gain. (Self)sacrifice in this sense does not require a victim, not even Harry having victimized himself. So, in a strict sense, 'self-sacrifice' in this context is a contradiction in terms. de l'essence, tr. by Alphonso Lingis; Pittsburgh: Duquesne University Press, 1998), 50.

34 It is of note that Levinas speaks of self-sacrifice in relation to maternity. The responsibility for the other is depicted as a kind of maternity, for one suffers like a mother who gives her life-blood for her child in "the complete being 'for the other' which characterizes it". Levinas, Otherwise than Being, 108. Cf. Welz, "Love as Gift and Self-Sacrifice," 245. 